\title{
Vitamin D Receptor and Vitamin D Binding Protein Gene Polymorphisms Are Associated with Renal Allograft Outcome
}

\author{
Sepideh Zununi Vahed ${ }^{1}{ }^{(D)}$, Elham Ahmadian ${ }^{1}\left(\mathbb{D}\right.$, Peyman Foroughi $^{1}$, Soroush Mostafavi ${ }^{1}$, Henning Madry $^{2}{ }^{(D)}$, \\ Mohammadreza Ardalan 1,*(D) and Magali Cucchiarini ${ }^{2, *(D)}$ \\ 1 Kidney Research Center, Tabriz University of Medical Sciences, Tabriz 5166615731, Iran; \\ sepide.zununi@gmail.com (S.Z.V.); ahmadian.elham@yahoo.com (E.A.); payman.foroughi@gmail.com (P.F.); \\ so.mostafavi@gmail.com (S.M.) \\ 2 Center of Experimental Orthopaedics, Saarland University Medical Center, D-66421 Homburg, Germany; \\ henning.madry@uks.eu \\ * Correspondence: ardalan34@yahoo.com (M.A.); mmcucchiarini@hotmail.com (M.C.); \\ Tel.: +98-914-116-8518 (M.A.); +49-68-4116-24987 (M.C.)
}

check for updates

Citation: Zununi Vahed, S.;

Ahmadian, E.; Foroughi, P.;

Mostafavi, S.; Madry, H.; Ardalan, M.; Cucchiarini, M. Vitamin D Receptor and Vitamin D Binding Protein Gene Polymorphisms Are Associated with Renal Allograft Outcome. Nutrients 2021, 13, 1101. https://doi.org/ 10.3390/nu13041101

Received: 16 January 2021

Accepted: 24 March 2021

Published: 27 March 2021

Publisher's Note: MDPI stays neutra with regard to jurisdictional claims in published maps and institutional affiliations.

Copyright: (c) 2021 by the authors. Licensee MDPI, Basel, Switzerland. This article is an open access article distributed under the terms and conditions of the Creative Commons Attribution (CC BY) license (https:/ / creativecommons.org/licenses/by/ $4.0 /)$.
Abstract: Vitamin D deficiency has adverse effects on renal allograft outcomes, and polymorphisms of genes encoding vitamin D-binding protein (VDBP) and vitamin D receptor (VDR) are defined to play a role in these conditions. The goal of the current investigation was to evaluate the connection between those polymorphisms with acute rejection, viral infection history, and recipients' vitamin D status. In this study, 115 kidney transplant recipients and 100 healthy individuals were included. VDR polymorphisms including FokI (rs2228570), Apal (rs7975232), BsmI (rs1544410), as well as VDBP (rs7040) polymorphisms were studied using high resolution melting (PCR-HRM) analysis among the studied groups. The frequency of $\mathrm{G}$ allele in Apal rs7975232 polymorphism in the kidney transplant recipients was 0.63 times lower than healthy individuals $(p=0.026)$. Further, the $\mathrm{G}$ allele frequency in VDBP rs7040 polymorphism was significantly lower in patients with allograft rejection $(p=0.002)$. Considering the incidence of viral infection, significant differences were identified between the frequencies of VDR FokI (OR $=2.035 ; 95 \%$ CI 1.06-2.89, $p=0.030)$ and VDBP rs7040 (OR = 0.40; 95\% CI $0.24-0.67, p<0.001) \mathrm{T}$ alleles in the studied groups. Moreover, the VDBP rs7040 GG genotype distribution was low in the recipients with a history of viral infection ( $p=0.004)$. VDR (FokI) and VDBP (rs7040) alleles and their genotype distribution are significantly associated with allograft outcomes including allograft rejection and viral infection in the studied population.

Keywords: kidney transplant; vitamin D; polymorphism; allograft rejection; viral infection; vitamin $\mathrm{D}$ binding protein; vitamin $\mathrm{D}$ receptor

\section{Introduction}

Kidney transplantation is associated with better survival, increased life quality, and reduced costs in comparison with dialysis [1]. However, acute graft rejection happens in around $20-40 \%$ of the recipients, and chronic rejection is still the main causes of diminished graft functionality $[2,3]$. Several studies have focused on the development of novel strategies to reduce transplantation rejection.

Vitamin D is a secosteroid hormone, whose metabolizing enzymes and its intracellular receptor (VDR) generate the active hormone and mediate its effect on the skeletal metabolism, tumor-inducing cascades, and immune responses [4]. Vitamin D regulates innate and adaptive immune systems and chemokine receptors [5], influencing monocytes differentiation, lymphocyte proliferation, and cytokine production [6]. Sufficient levels of vitamin D stimulate the innate immune system through the toll-like receptors (TLRs) in the immune cells. The stimulation of TLRs in the immune cell stimulates the generation of anti-microbial peptides (AMPs) such as reactive oxygen species (ROS), and cathelicidin that further kill the intracellular microorganism. Moreover, vitamin D mediates immunologic 
tolerance [7] as it prohibits the maturation of dendritic cells, and thus prevents the further activation of immune cells [8]. These cellular effects of vitamin D are mediated by its receptor. The activation of VDR by 1,25-dihydroxyvitamin $\mathrm{D}_{3}\left[1,25(\mathrm{OH})_{2} \mathrm{D} 3\right]$, as a nuclear transcription factor, regulates the expression of more than one thousand genes in different tissues [9].

Vitamin D and all its metabolites are transported by a multifunctional vitamin $\mathrm{D}$ binding protein (VDBP). With a high affinity, $\mathrm{DBP}$ binds to $1,25(\mathrm{OH})_{2} \mathrm{D}_{3}$ and 25-hydroxyvitamin $\mathrm{D}$ [25OHD] that generate a circulating $25 \mathrm{OHD}$ pool, inhibiting rapid deficiency of vitamin D. Moreover, VDBP regulates the access of the metabolites of vitamin D to tissues and cells $[10,11]$.

Vitamin D has also a potential effect on kidney allografts maintenance [12]. Vitamin D may decline the dose of immunosuppressive drugs (especially calcineurin inhibitors), resulting in a reduction of their nephrotoxicity and infectious complications. Moreover, according to the assisting knowledge, vitamin D can plummet the development of chronic allograft injury [13]. In this regard, deficiency of vitamin D is concomitant with adverse outcomes of transplanted allograft including reduced glomerular filtration rate (GFR) and increased risk of graft rejection and infections [14,15].

The role of genetic alterations such as polymorphisms and mutations in VDR and VDBP have also been postulated to modulate immune response after allograft transplantation [16-18]. However, the current data are limited and require further investigations. Therefore, the present experiment was intended to evaluate the connection between VDR and VDBP gene polymorphisms with kidney allograft function and outcomes including viral infection and allograft rejection.

\section{Materials and Methods}

\subsection{Study Subjects}

This retrospective study was conducted on the kidney transplant recipients of Imam Reza Hospital, Tabriz, Iran. The inclusion criteria were living non-related donors, having undergone kidney transplantation at least three years earlier, and both males and females gender between 15 to 60 years old. The exclusion criteria were included age ranges beyond those inclusion limits, kidney allograft malfunction related to urologic problems such as obstruction and kidney stone, a history of kidney transplantation (second or third transplantation), and kidney recipients suffering from kidney failure due to systemic or organ-specific reasons (sepsis, pneumonia, myocardial infarction, trauma, etc.). Level of vitamin $\mathrm{D}$, clinical information, and medicine were recorded. Moreover, evidence on allograft rejection and a prior history of cytomegalovirus (CMV) and BK polyomavirusa (BK) infections were recorded as allograft outcomes. GFR was calculated by the formula of modification of diet in the renal disease $\left(\right.$ MDRD) GFR $=175 \times(\text { serum creatinine }(\mathrm{mg} / \mathrm{dL}))^{-1.154}$ $\times(\text { age in years })^{-0.203} \times(0.742$ if female $\left.)\right)$ [19]. Overall, the participants were categorized in four groups, based on third year allograft function defined by their GFR as the followings; acceptable allograft function was defined as (GFR $>45$ ), moderate to severe graft dysfunction was defined as GFR ranged between $(45<$ GFR $>10)$, and those with poor allograft function had a dropped GFR below $10 \mathrm{~mL} / \mathrm{min} / 1.73 \mathrm{~m}^{2}$. One hundred healthy individuals were also employed as the control group and compared with the case group. The Ethics Committee of Tabriz University of Medical Sciences, Tabriz, Iran approved this work (IR.TBZMED.REC.1397.155). Subjects agreed to participate in this study by signing written informed consent.

\subsection{Genetic Study}

For running a genetic check from the individuals under study, $2^{\mathrm{CC}}$ blood samples were collected and kept frozen in $\mathrm{CBC}$ pipes in $-20^{\circ} \mathrm{C}$ till DNA extraction. Genomic DNAs were extracted using a manual protocol [20]. The study of VDR polymorphisms including FokI C>T (rs2228570), Apal T>C (rs7975232), BsmI G>A (rs1544410) as well as VDBP (rs7040) polymorphisms were performed using high resolution melting (PCR-HRM) 
analysis. The primer sequences are listed in Table 1. The PCR cycling condition was as follows: a preliminary denaturation at $94^{\circ} \mathrm{C}$ for $10 \mathrm{~min}$, followed by $94{ }^{\circ} \mathrm{C}$ for $10 \mathrm{~s}, 59^{\circ} \mathrm{C}$ for $30 \mathrm{~s}$, and $72{ }^{\circ} \mathrm{C}$ for $20 \mathrm{~s}$ for 40 cycles. In order to check for the accuracy of the sample size, some samples were sent to Macrogen Company in Korea for sequencing.

Table 1. Primer sequences.

\begin{tabular}{|c|c|c|c|}
\hline Polymorphisms & Position & Description & Sequences $\left(5^{\prime}-3^{\prime}\right)$ \\
\hline rs2228570 & $\begin{array}{l}\text { chr12:47879112 } \\
\text { (GRCh38.p12) }\end{array}$ & $\begin{array}{l}\text { NG_008731.1:g.30920T > G; } \\
\text { NG_008731.1:g.30920T > C; } \\
\text { NG_008731.1:g.30920T > A }\end{array}$ & $\begin{array}{l}\text { F: 5'-GTGGGTGGCACCAAGGAT-3' } \\
\text { R: GTCTCCACACACCCCACAGAT-3' }\end{array}$ \\
\hline rs1544410 & $\begin{array}{l}\text { chr12:47846052 } \\
\text { (GRCh38.p12) }\end{array}$ & $\begin{array}{l}\text { NG_008731.1:g.63980G > T; } \\
\text { NG_008731.1:g.63980G > C; } \\
\text { NG_008731.1:g.63980G > A }\end{array}$ & $\begin{array}{c}\text { F: 5'-CTGGGGCCACAGACAGG-3' } \\
\text { R: CCTGCCCGCAAGAAACCTCAA-3' }\end{array}$ \\
\hline $\begin{array}{l}\text { rs795232 } \\
\text { rs7040 }\end{array}$ & $\begin{array}{l}\text { chr12:47845054 } \\
\text { (GRCh38.p12) }\end{array}$ & NG_008731.1:g.64978G > T & $\begin{array}{c}\text { F: } 5^{\prime} \text {-GGCAGTGGTATCACCGGTCAG-3' } \\
\text { R: } 5^{\prime} \text {-CTGTGGGCACGGGGATAGAGA-3' } \\
\text { F: } 5^{\prime}-\text { TTGCCTGATGCCACACCC-3' } \\
\text { R: } 5^{\prime} \text {-GGAACAGCAGTTGGAGGCAAA-3' }\end{array}$ \\
\hline
\end{tabular}

\subsection{Statistical Analysis}

The data were tested for normality. For parametric factors, differences between the groups were tested via the Student t-test and expressed as mean and standard deviation (SD). For non-parametric variables, differences between the groups were tested via the Mann-Whitney $U$ test and expressed as median (Interquartile Range). The genotype distribution of polymorphisms was tested by the Chi-square test. The correlation of these polymorphisms with graft survival and function were evaluated using Pearson coefficient correlation and logistic regression analysis. Data analysis was done using SPSS Version 22 (Chicago). $p$-value $<0.05$ was considered statistically significant.

\section{Results}

Out of 200 renal recipients, 115 patients ( 72 males / 43 females) were included (Figure 1). The demographic and clinical characteristics of the participants are presented in Table 2. Participants were examined in terms of VDR and VDBP polymorphisms. Most of the kidney recipients were treated by a triple immunosuppression therapy including corticosteroids (prednisolone), mycophenolate mofetil (MMF), and Tacrolimus that was tailored based on measured plasma levels.

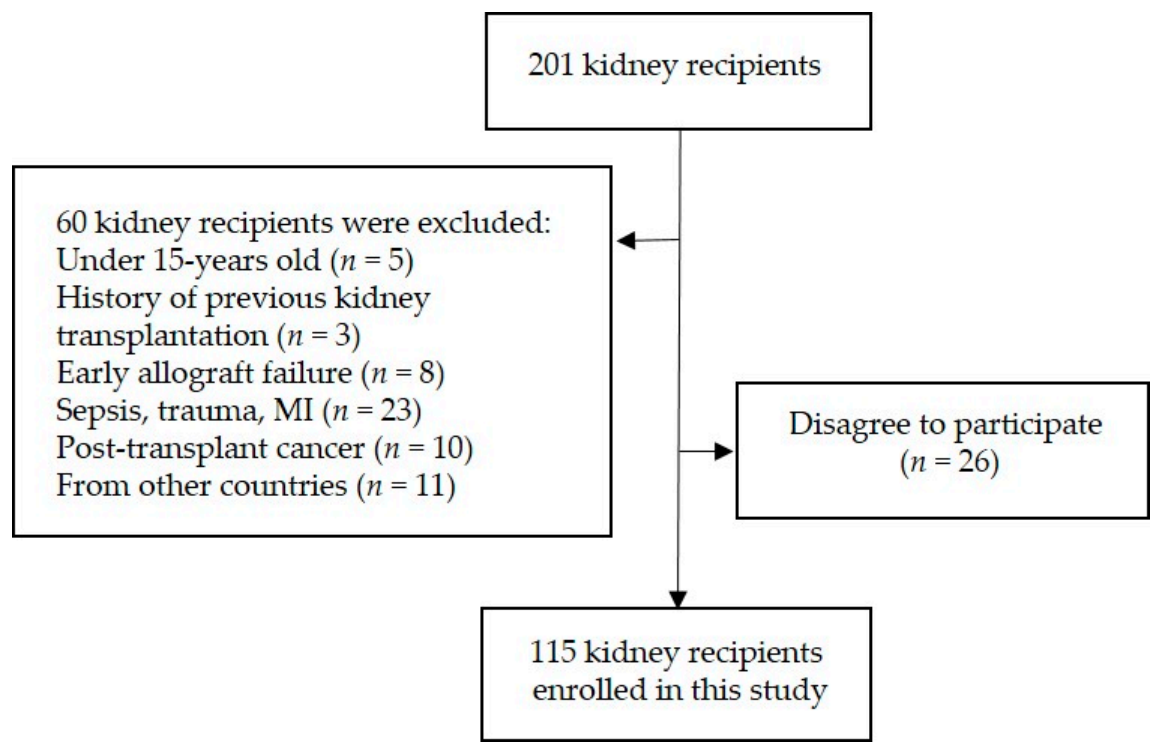

Figure 1. A flow-chart of patients selection. 
Table 2. Demographic and baseline clinical data.

\begin{tabular}{|c|c|c|c|}
\hline Variables & Controls & Cases & $p$-Value \\
\hline No. of cases & 100 & 115 & - \\
\hline \multicolumn{4}{|l|}{ Demographic characteristics } \\
\hline Age mean $\pm \mathrm{SD}$ (years) & $41.3 \pm 3.2$ & $41.8 \pm 5.3$ & 0.760 \\
\hline Gender, Male, $n(\%)$ & $58(58 \%)$ & $72(62.6 \%)$ & \\
\hline Female, $n(\%)$ & $32(32 \%)$ & $43(37.4 \%)$ & $0.810^{\mathrm{a}}$ \\
\hline $\mathrm{BMI}, \mathrm{Kg} / \mathrm{m}^{2}($ mean $\pm \mathrm{SD})$ & $20.92 \pm 4.70$ & $22.43 \pm 3.30$ & $p=0.125$ \\
\hline Smoking history, $n(\%)$ & $25(10)$ & $15(7)$ & $p=0.092^{a}$ \\
\hline \multicolumn{4}{|l|}{ Clinical characteristics } \\
\hline Urea $(\mathrm{mg} / \mathrm{dL})$ & $27.46 \pm 1.7$ & $58.02 \pm 23.7$ & $<0.001$ \\
\hline Serum creatinine $(\mathrm{mg} / \mathrm{dL})$ & $1.04 \pm 0.1$ & $1.53(1.15)$ & $<0.001^{\mathrm{b}}$ \\
\hline Serum Calcium (mg/dL) & $8.99 \pm 0.75$ & $7.16 \pm 1.27$ & $p=0.041$ \\
\hline Phosphate (mg/dL) & $3.8 \pm 0.42$ & $4.61 \pm 0.81$ & $p=0.030$ \\
\hline Serum $25(\mathrm{OH}) \mathrm{D}(\mathrm{ng} / \mathrm{mL})$ & $40.02(14.38)$ & $16.50(20.38)$ & $p<0.001^{\mathrm{b}}$ \\
\hline GFR $\left(\mathrm{mL} / \mathrm{min} / 1.73 \mathrm{~m}^{2}\right)$ & $84.65(20.12)$ & $59.89(31.32)$ & $<0.001^{\mathrm{b}}$ \\
\hline PTH $(\mathrm{pg} / \mathrm{mL})$ & $43(15)$ & $141(30)$ & $p=0.024^{b}$ \\
\hline Hemoglobin ${ }^{c}$ & $14.71 \pm 1.84$ & $11.42 \pm 5.23$ & $p=0.051$ \\
\hline Albumin $(g / d L){ }^{d}$ & $4.31 \pm 0.95$ & $3.24 \pm 1.03$ & $p=0.062$ \\
\hline Pre-transplant dialysis (months) & - & $25.60 \pm 10.45$ & \\
\hline $\begin{array}{l}\text { Time post-transplantation } \\
\text { (months) }\end{array}$ & - & $65(40.21)$ & \\
\hline \multicolumn{4}{|l|}{ Underlying ESRD, $n(\%)$} \\
\hline Glomerulonephritis & - & $48(41.73)$ & \\
\hline Interstitial nephropathy & - & $31(26.95)$ & \\
\hline Diabetic & - & $14(12.17)$ & \\
\hline Hypertension & - & $9(7.82)$ & \\
\hline Unknown & - & $5(4.37)$ & \\
\hline Polycystic kidney disease & - & $3(2.60)$ & \\
\hline Vasculitis & - & $3(2.60)$ & \\
\hline Reflux nephropathy & - & $2(1.73)$ & \\
\hline \multicolumn{4}{|l|}{$\begin{array}{l}\text { Post-transplant complications, } n \\
\qquad(\%)\end{array}$} \\
\hline DGF & - & $5(4.34)$ & \\
\hline Acute allograft rejection & - & $25(21.70)$ & \\
\hline Chronic graft dysfunction ${ }^{\mathrm{e}}$ & - & $23(20)$ & \\
\hline New-onset diabetes & - & $9(7.8)$ & \\
\hline $\mathrm{CMV}, n(\%)$ & - & $20(17.4)$ & \\
\hline BK polyomavirus, $n(\%)$ & - & $16(13.9)$ & \\
\hline $\mathrm{CMV}+\mathrm{BK}$ polyomavirus, $n(\%)$ & - & $19(16.5)$ & \\
\hline CMV + Parvovirus & - & $1(0.87)$ & \\
\hline Chronic allograft failure ${ }^{f}$ & - & $15(13.04)$ & \\
\hline Recipients survival & - & $115(100)$ & \\
\hline
\end{tabular}

eGFR: estimated glomerular filtration rate; ESRD: end-stage renal disease; DGF: Delayed graft function, 25(OH)D: 25 -hydroxyvitamin D. Numbers are presented as mean \pm SD. ${ }^{a}$ Number $(\%)$ is presented. $p$-value is based on Chi-squared test. ${ }^{b}$ Median (Interquartile Range) is presented and $p$-value is based on Mann-Whitney U test. ${ }^{c}$ Data on Hemoglobin did not available for 5 recipients. ${ }^{d}$ Data on Albumin did not available for 11 recipients. ${ }^{e}$ Chronic graft dysfunction is defined as $\mathrm{Cr}>3$ and GFR $\leq 22.9 .{ }^{\mathrm{f}}$ Chronic allograft failure is considered as $\mathrm{Cr}>5$, GFR $\leq 10$, and a need for hemodialysis.

\subsection{Frequencies of VDR and VDBP Alleles and Genotypes Distribution}

The frequency of alleles and genotypes distribution in ApaI (rs7975232) are shown in Figure 2A,B. The results showed that the $G$ allele frequency in rs7975232 polymorphism in the control group was significantly 0.63 times more than that of the case group $(p=0.026)$. There were differences between the two groups concerning the distribution of TT, GG, and GT genotypes of rs7975232; however, they were not statistically noteworthy $(p=0.058)$. Comparing the case and control group, concerning the frequency of FokI (rs2228570) G and T alleles ( $p=0.234)$, no significant difference was observed (Figure 2C). Furthermore, the frequency of rs2228570 genotypes (GG, GT, and TT) was not statistically significant be- 
tween the groups $(p=0.629)$ (Figure 2D). Similarly, no significant differences were detected between the frequency of T and C alleles $(p=0.710)$ and that of CC, CT, and TT genotypes ( $p=0.819$ ) of the Bsml genotype (rs1544410) between the two groups (Figure 3A,B). Furthermore, no significant difference was detected in the frequency of $\mathrm{G}$ and $\mathrm{T}$ alleles ( $p=0.056)$ and that of the GG, GT, and TT genotypes of rs7040 $(p=0.230)$ between the case and control groups (Figure 3C,D).

\subsection{VDR and VDBP Gene Polymorphisms Based on Allograft Rejection}

Out of the 115 cases of kidney transplants, $21.7 \%$ had a history of transplant rejection. The comparison of the frequency of VDR and VDBP alleles and genotypes distribution, concerning the graft rejection are depicted in Figure 4. As it can be seen, no significant difference was shown concerning the frequency of $\mathrm{G}$ and $\mathrm{T}$ alleles $(p=0.691)$ and the distribution of rs7975232 genotypes ( $p=0.266$ ), regarding the graft rejection (Figure $4 \mathrm{~A}, \mathrm{~B}$ ). Similarly, in the rs2228570 genotype, there was no significant difference in the frequency of $\mathrm{G}$ and T alleles $(p=0.281)$ and the distribution of the GG, GT, and TT genotypes $(p=0.428)$ between the acute rejection and the control groups (Figure 4C,D). Additionally, no significant change was detected between the frequency of T and C alleles $(p=0.689)$ and the distribution of the rs1544410 genotypes (CC, CT, and TT) $(p=0.361)$ (Figure 4E,F). As it can be seen in Figure 4G, the frequency of the $G$ allele in the rs7040 genotypes was significantly low $(p=0.002)$ in patients with allograft rejection. Moreover, this allele increased the risk of transplant rejection to 0.27. The distributions of rs7040 GG and GT genotypes were lower in the rejection group; however, they were not statistically significant $(p=0.096)$ (Figure $4 \mathrm{H})$.
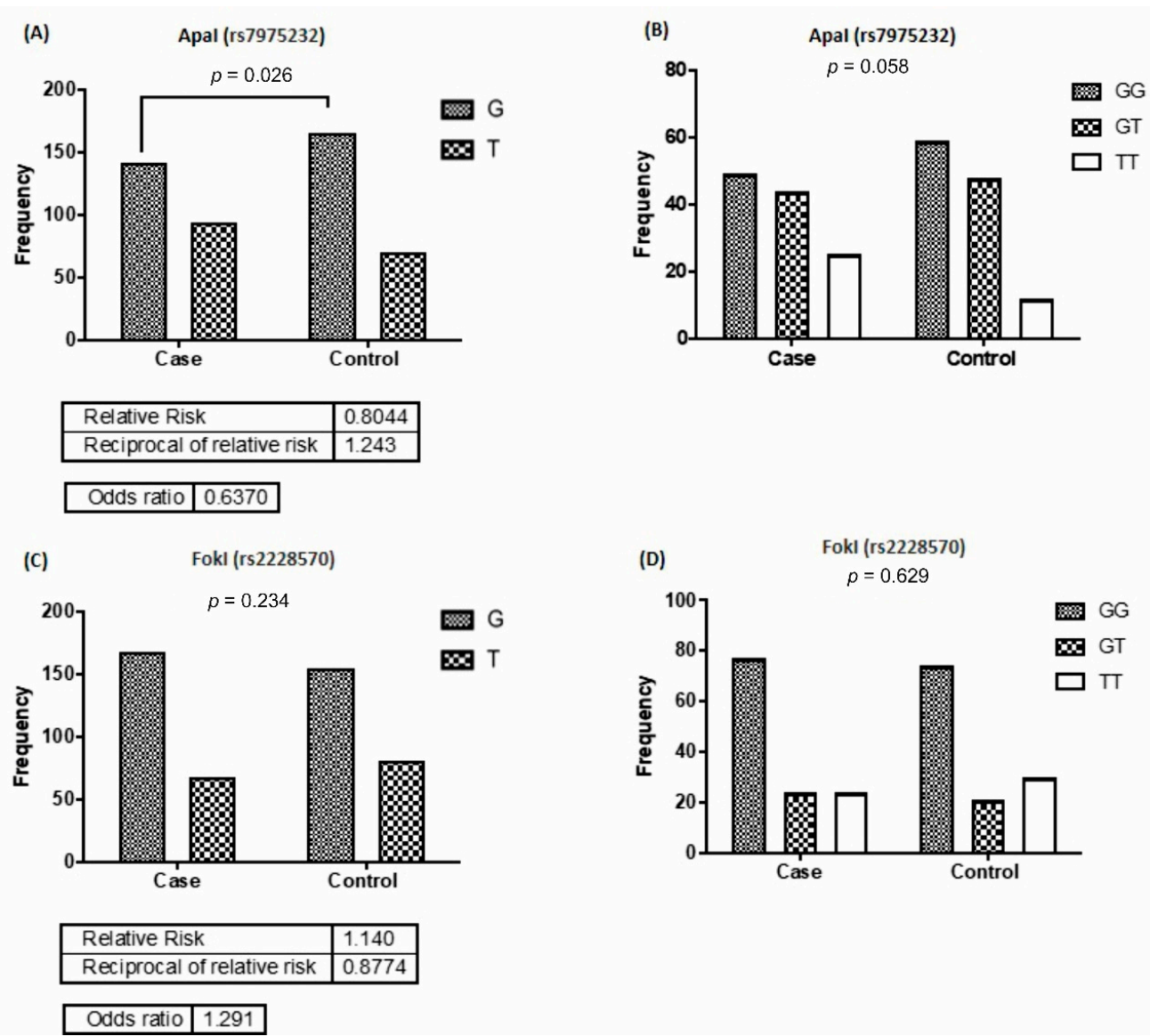

Figure 2. Allele and genotype frequencies of vitamin D receptor (VDR) polymorphisms in the studied groups. Comparing the ApaI (A,B) and FokI (C,D) polymorphisms in kidney recipients and control groups. 

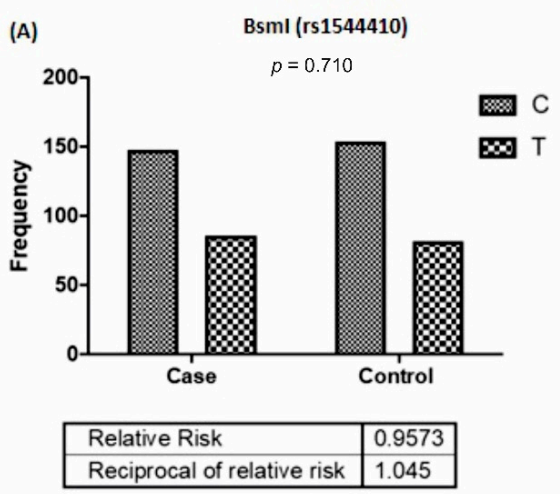

\begin{tabular}{|l|l|l|}
\hline Odds ratio & 0.9163 \\
\hline
\end{tabular}

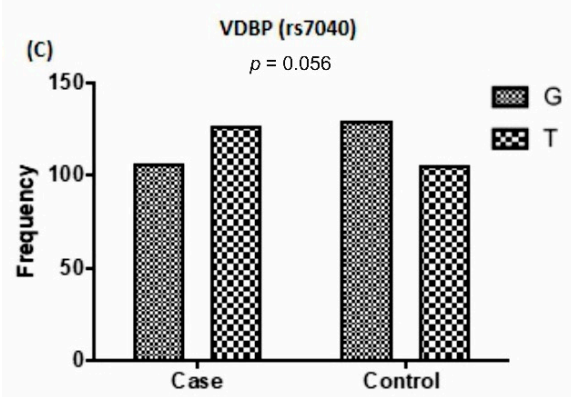

\begin{tabular}{|l|l|}
\hline Relative Risk & 0.8283 \\
\hline Reciprocal of relative risk & 1.207 \\
\hline
\end{tabular}

\begin{tabular}{|l|l|}
\hline Odds ratio & 0.6870 \\
\hline
\end{tabular}
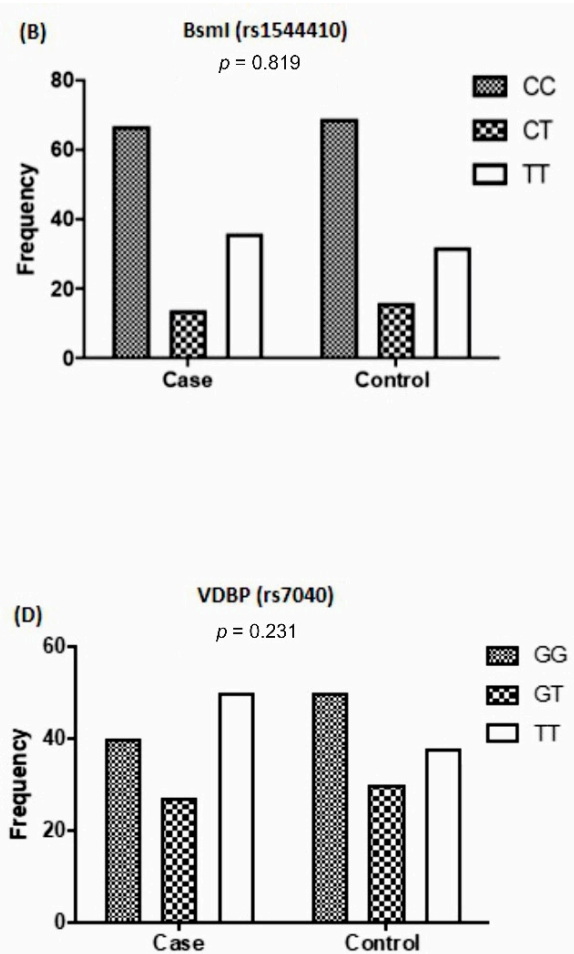

Figure 3. Allele and genotype frequencies of BsmI and vitamin D-binding protein (VDBP) rs7040 polymorphisms in the studied groups. Comparing the BsmI (A,B) and rs7040 (C,D) polymorphisms between kidney recipients and control groups.

\subsection{The Frequency of VDR and VDBP Gene Polymorphisms Based on Viral Infection}

The comparison of the frequency of the studied genotype alleles, regarding the history of viral infections is depicted in Figure 5. No significant differences were observed in the frequency of $\mathrm{G}$ and $\mathrm{T}$ alleles $(p=0.302)$ and the distribution of the Apal genotypes between the recipients with the history of viral infection and the controls (Figure 5A,B). In the rs2228570 genotype, the frequency of $T$ allele in patients with a history of viral infection was significantly lower than the controls $(p=0.030)$. This $\mathrm{T}$ allele showed a risk history of viral infections (Odd ratio $=2.035$ ) (Table 3). The distribution of the TT rs2228570 genotype was also lower in the recipients with a history of viral infection, however, it was not significant $(p=0.074)$ (Figure 5C,D). The frequency of $\mathrm{C}$ and T alleles $(p=0.703)$ and the distribution of rs1544410 genotypes $(p=0.804)$ displayed no significant difference between the control and viral infection groups (Figure $5 \mathrm{E}, \mathrm{F}$ ). 

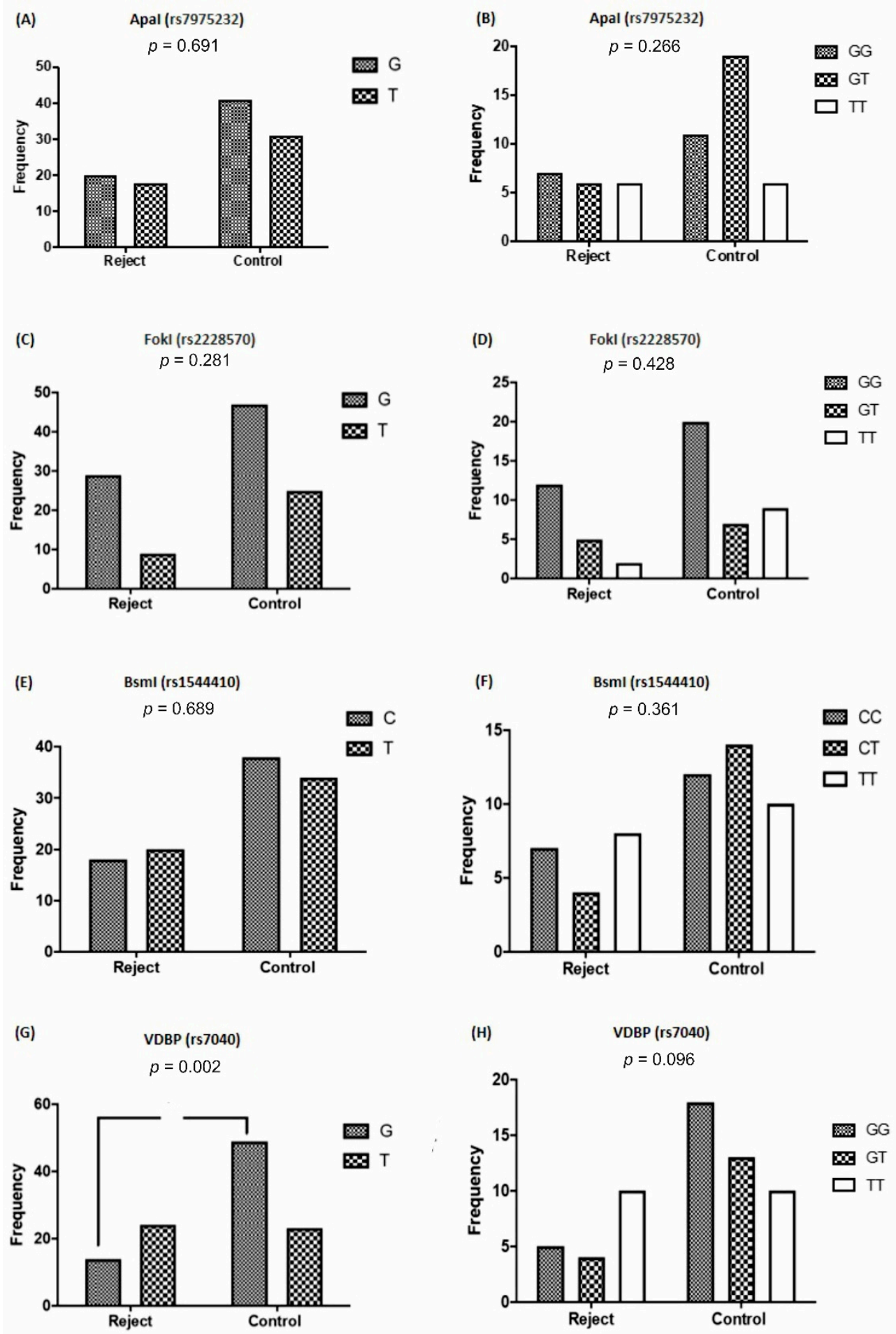

Figure 4. Frequencies of VDR and VDBP polymorphisms in the allograft rejection and healthy groups. (A,B) ApaI, (C,D) FokI, (E,F) BsmI, and (G,H) rs7040 polymorphisms. VDR: vitamin D receptor; VDBP: vitamin D-binding protein. 

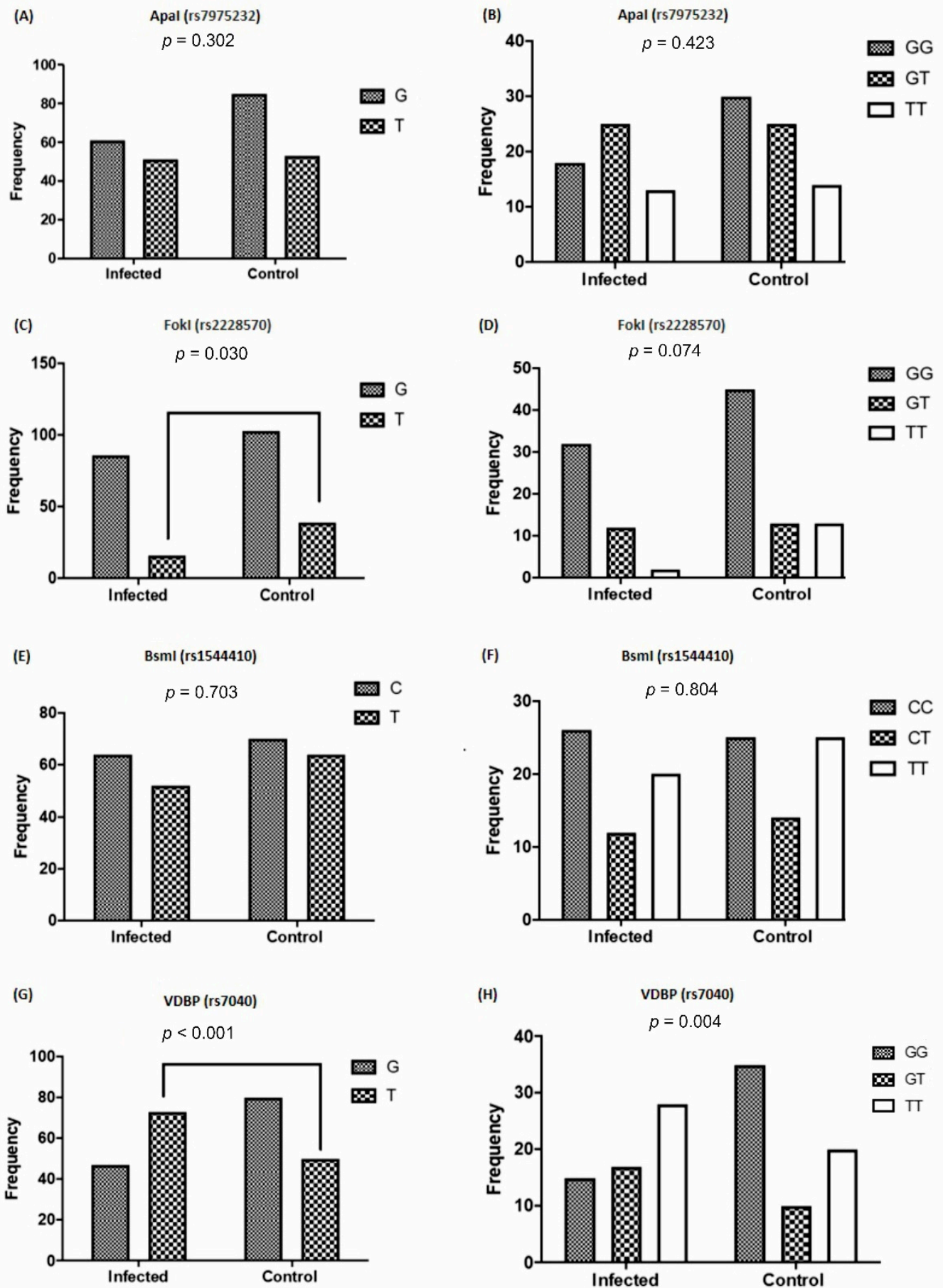

Figure 5. Comparison of the allele and genotype frequencies of VDR and VDBP polymorphisms in the recipients with a history of viral infection and healthy individuals. (A,B) ApaI, (C,D) FokI, (E,F) BsmI, and (G,H) rs7040 polymorphisms. VDR: vitamin D receptor; VDBP: vitamin D-binding protein. 
Table 3. The correlation between the genotypes and the allograft outcome.

\begin{tabular}{ccc}
\hline Risk Factors & OR $\mathbf{( 9 5 \% \mathbf { C I } )}$ & $p$ Value \\
\hline rs1544410 and graft rejection & 0.8053 & 0.6892 \\
rs2228570 and graft survival & 1.714 & 0.2817 \\
rs7975232 and graft survival & 0.8401 & 0.6910 \\
rs7040 and graft survival & 0.2738 & $\mathbf{0 . 0 0 2 3}$ \\
rs1544410 and viral infection & 1.125 & 0.7032 \\
rs2228570 and viral infection & 2.035 & $\mathbf{0 . 0 3 0 9}$ \\
rs7975232 and viral infection & 0.7458 & 0.3021 \\
rs7040 and viral infection & 0.4024 & $\mathbf{0 . 0 0 0 6}$ \\
\hline
\end{tabular}

OR: odds ratio. $p$ values $<0.05$ are shown in bold.

The $\mathrm{T}$ allele frequency of rs7040 was significantly higher in cases with viral infections $(p<0.001)$ compared with the controls, with an Odd ratio of 0.40 (Table 3). Moreover, the distribution of the GG genotype of rs7040 was significantly lower $(p=0.004)$ in cases with a history of viral kidney infection compared with the controls (Figure $4 \mathrm{G}, \mathrm{H}$ ).

\subsection{Connection of Vitamin D Levels with VDR and VDBP Gene Polymorphisms}

The comparison of various VDBP and VDR polymorphisms genotypes, pertaining to the amount of vitamin $\mathrm{D}$ in the patients under study indicated that there was no difference between the frequencies of various polymorphisms genotypes distribution related to vitamin D ( $p \geq 0.410)$, Figure 6A,B.

(A)

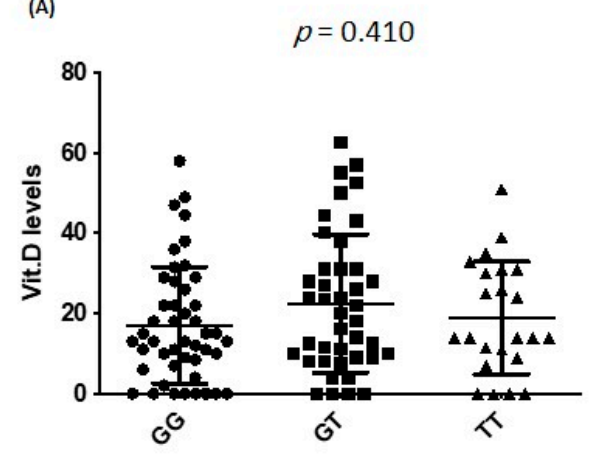

Genotype
(B)

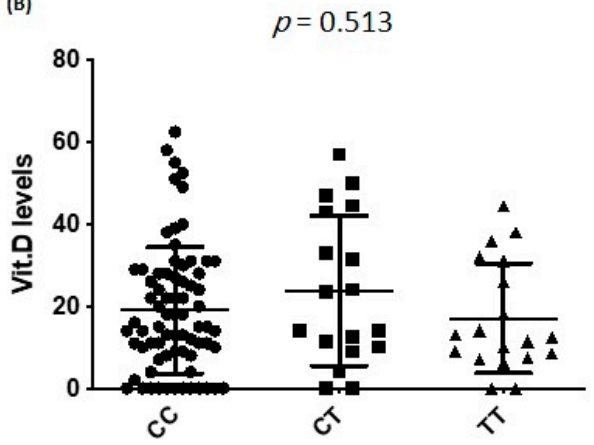

Genotype

Figure 6. Association of vitamin D status with VDR and VDBP gene polymorphisms. Association of vitamin D status with (A) VDR and (B) VDBP genotypes. VDR: vitamin D receptor; VDBP: vitamin D-binding protein.

\section{Discussion}

Our results showed that the VDR (FokI) and VDBP (rs7040) alleles and their genotype distribution were significantly associated with graft outcome. The $\mathrm{G}$ allele frequency in VDBP rs7040 polymorphism was significantly lower in recipients with allograft rejection. In the Apal rs7975232 polymorphism, the frequency of the $\mathrm{G}$ allele in the kidney transplant recipients was lower than those of the healthy individuals. Significant variances were detected between the frequencies of the VDR FokI and VDBP rs7040 alleles and viral infection in the studied groups. Moreover, the GG genotype distribution was low in recipients with a history of viral infection.

The recent discovery of VDR and its abundant binding sites have surged an interest to study its effect in different biological processes throughout the body [7]. The nutritional deficit, lower physical inactivity, low sunlight exposure, and elevated amounts of fibroblast growth factor 23 (FGF-23) can cause vitamin D deficiency. Additionally, decreased serum albumin, liver malfunction, diabetes, and corticosteroid therapy are attributed to 
decreased vitamin D levels post-transplantation [21]. Up to $97 \%$ of cases had vitamin D insufficiency and about $39 \%$ of patients exhibited vitamin D deficiency after organ transplantation [22]. Vitamin D insufficiency has been detected not only for a short period after kidney transplant, but also for a very long time in patients never supplemented with sterols [23]. In a cross-sectional investigation ( $n=94$ patients), renal graft recipients with lower levels of 25(OH)D exhibited a higher rate of acute rejection [24]. In another investigation, it was shown that patients with $25(\mathrm{OH}) \mathrm{D}$ levels less than $10 \mathrm{ng} / \mathrm{mL}$ were more exposed to acute rejections [14] proposing the potentially pivotal role of vitamin $\mathrm{D}$ in the preservation of graft function. A cut-off level of $15 \mathrm{ng} / \mathrm{mL}$ three months after transplantation was suggested to be an independent risk factor for GFR decline and tubular atrophy and fibrosis one year after transplantation [25]. Even though the exact mechanism of this association is unknown, the role of genetic variations of VDR and VDBP should be taken into account. Different polymorphisms have been recognized in the VDR gene on chromosome 12. Examples include RFLPs such as Tru9I, BsmI, TaqI, ApaI, and EcoRV in exons 8 and $9[18,26,27]$. Moreover, a $T$ to $C$ variation in exon 2 generated another RFLP in the VDR gene termed FokI [28]. It has been shown that two genetic variations in VDBP (rs7040, rs4588) can result in alterations in the sequence and function of this protein [6]. VDR polymorphisms are associated with adverse outcomes of transplantation such as the increased risk of graft rejection and viral infections [14,15], the severity of secondary hyperparathyroidism, bone density of kidney recipients [29], and an increased risk for bone diseases after transplantation [30]. It is also reported that the VDR FokI polymorphism is a genetic risk factor for the development of post-transplantation diabetes mellitus [31].

Falleti et al. proved that the presence of $\mathrm{G}^{-*}-\mathrm{T} / \mathrm{G}^{*}-\mathrm{T}$ diplotypes of the TaqI T $>\mathrm{C}$, ApaI T > G, and BsmI G > A polymorphisms were connected with a high risk of acute cellular rejection and CMV infection in liver transplanted patients [32]. However, connection between BsmI and FokI polymorphisms and the incidence of acute rejection was not proved in another study [33]. Moreover, the association between kidney allograft survivals with VDR FokI T allele has been reported; however, no significant association was found between acute rejection and ApaI and FokI genotypes [34]. Similar to this result, in the present work, no statistically significant association was observed between the Apal, BsmI, and FokI genotypes and acute rejection. In patients with the rs4588 VDBP polymorphisms, the GC genotype has been in relation with increased rate of graft survival in kidney transplantation [16]. In our study also, in VDBP rs7040 polymorphism, the G allele frequency significantly was lower in patients with transplant rejection with an Odd ratio of 0.27 .

It has been shown that $1,25(\mathrm{OH})_{2} \mathrm{D}$ triggers the expression of TLR2 and cathelicidin in epithelial and myeloid cells [35]. Moreover, it is increased as a defense against M. tuberculosis infection [36]. In addition, $1,25(\mathrm{OH})_{2} \mathrm{D}$ prohibits the development of interferon-gamma and interleukin 2 (IL-2) generating Th1 and Th17 cells [37]. Several studies have explored the connection between certain viral infections such as the Epstein-Barr virus (EBV), human immunodeficiency virus (HIV), hepatitis B and C, and influenza and vitamin D levels [38]. However, the result of a study showed that vitamin D deficiency independently increases the rejection risk, but does not escalate the risk of BK and CMV infection in 90 days monitoring post-transplantation $[12,15]$.

In our study, significantly high frequency of the T allele and low distribution of GG genotype in VDBP rs7040 genotype were seen in recipients with a history of viral infection. Moreover, low frequency of the VDR FokI T allele was observed in this group compared with the controls. Our Logistic regression analysis showed that the VDR FokI and VDBP rs7040 polymorphisms could significantly increase the Odds ratio of viral infection.

The main limitation of this study was the lack of the biologically active form of Vitamin $\mathrm{D}\left(1,25(\mathrm{OH})_{2} \mathrm{D}\right)$ measurement that could more identify the pathogenic link between posttransplant outcome (viral infection and graft rejection) and vitamin D status. Small sample size was another limitation of this study that may affect the strength of the findings. 


\section{Conclusions}

Overall, the results imply that (i) a low frequency of the $\mathrm{G}$ allele of the ApaI polymorphism exists in kidney transplant cases, (ii) a low frequency of the $G$ allele of the rs7040 polymorphism is associated with poor graft function or rejection, (iii) a low frequency of the $\mathrm{T}$ allele of the FokI polymorphism and a high frequency of the $\mathrm{T}$ allele and a low GG genotype distribution in the rs7040 VDBP polymorphism are associated with viral infections in kidney recipients. VDR FokI and VDBP rs7040 polymorphisms may be the genetic factors correlated with renal allograft outcomes in our population.

Author Contributions: M.A. cooperated in the design of the study and selecting the patients. P.F. and S.M. contributed to sampling and data analysis. E.A. and H.M. prepared the first draft. S.Z.V. contributed to preparing and revising the manuscript. M.C. contributed to revising the manuscript. All authors have read and agreed to the published version of the manuscript.

Funding: This study was granted by the Kidney Research Center of Tabriz University of Medical Sciences, Tabriz, Iran (Grant \# 59191).

Institutional Review Board Statement: The study was conducted according to the guidelines of the Declaration of Helsinki, and approved by the Ethics Committee of Tabriz University of Medical Sciences, Tabriz, Iran approved this work (IR.TBZMED.REC.1397.155, 2018 May 14).

Informed Consent Statement: Informed consent was obtained from all subjects involved in the study.

Data Availability Statement: The data presented in this study are available on request from the corresponding author.

Acknowledgments: The authors wish to express their appreciation to the Kidney Transplantation Ward of Imamreza hospital, Tabriz, Iran. This work was supported by the Saarland University within the funding program Open Access Publishing.

Conflicts of Interest: The authors declared no conflict of interest.

\section{References}

1. Rees, M.A.; Dunn, T.B.; Kuhr, C.S.; Marsh, C.L.; Rogers, J.; Rees, S.E.; Cicero, A.; Reece, L.J.; Roth, A.E.; Ekwenna, O.; et al. Kidney exchange to overcome financial barriers to kidney transplantation. Arab. Archaeol. Epigr. 2016, 17, 782-790. [CrossRef] [PubMed]

2. Lipworth, L.; Mumma, M.T.; Cavanaugh, K.L.; Edwards, T.L.; Ikizler, T.A.; Tarone, R.E.; McLaughlin, J.K.; Blot, W.J. Incidence and predictors of end stage renal disease among low-income blacks and whites. PLoS ONE 2012, 7, e48407. [CrossRef] [PubMed]

3. Choi, A.I.; Rodriguez, R.A.; Bacchetti, P.; Bertenthal, D.; Hernandez, G.T.; O'Hare, A.M. White/black racial differences in risk of end-stage renal disease and death. Am. J. Med. 2009, 122, 672-678. [CrossRef] [PubMed]

4. Haussler, M.R.; Whitfield, G.K.; Haussler, C.A.; Hsieh, J.-C.; Thompson, P.D.; Selznick, S.H.; Dominguez, C.E.; Jurutka, P.W. The nuclear vitamin D receptor: Biological and molecular regulatory properties revealed. J. Bone Miner. Res. 1998, 13, 325-349. [CrossRef]

5. Prietl, B.; Treiber, G.; Pieber, T.R.; Amrein, K. Vitamin D and Immune Function. Nutrients 2013, 5, 2502-2521. [CrossRef] [PubMed]

6. Uitterlinden, A.G.; Fang, Y.; van Meurs, J.B.; Pols, H.A.; van Leeuwen, J.P. Genetics and biology of vitamin D receptor polymorphisms. Gene 2004, 338, 143-156. [CrossRef]

7. Bikle, D.D. Vitamin D Metabolism, mechanism of action, and clinical applications. Chem. Biol. 2014, 21, 319-329. [CrossRef]

8. Aranow, C. Vitamin D and the immune system. J. Investig. Med. 2011, 59, 881-886. [CrossRef]

9. Zmijewski, M.A.; Carlberg, C. Vitamin D receptor(s): In the nucleus but also at membranes? Exp. Dermatol. 2020, 29, 876-884. [CrossRef] [PubMed]

10. Chun, R.F.; Shieh, A.; Gottlieb, C.; Yacoubian, V.; Wang, J.; Hewison, M.; Adams, J.S. Vitamin D Binding protein and the biological activity of vitamin D. Front. Endocrinol. 2019, 10, 718. [CrossRef]

11. Bouillon, R.; Schuit, F.; Antonio, L.; Rastinejad, F. Vitamin D binding protein: A historic overview. Front. Endocrinol. 2020, 10, 910. [CrossRef]

12. Lee, J.R.; Dadhania, D.; August, P.; Lee, J.B.; Suthanthiran, M.; Muthukumar, T. Circulating levels of 25-hydroxyvitamin D and acute cellular rejection in kidney allograft recipients. Transplantation 2014, 98, 292-299. [CrossRef]

13. Thiem, U.; Borchhardt, K. Vitamin D in solid organ transplantation with special emphasis on kidney transplantation. Vitam. Horm. 2011, 86, 429-468. [CrossRef] [PubMed]

14. Kim, H.; Kang, S.-W.; Yoo, T.-H.; Kim, M.S.; Kim, S.I.; Kim, Y.S.; Choi, K.H. The impact of pretransplant 25-hydroxy vitamin D deficiency on subsequent graft function: An observational study. BMC Nephrol. 2012, 13, 22. [CrossRef] [PubMed]

15. Saber, A.; Fotuhi, F.; Rostami, Z.; Einollahi, B.; Nemati, E. Vitamin D levels after kidney transplantation and the risk of cytomegalovirus infection. Nephrourol. Mon. 2015, 7, e29677. [CrossRef] 
16. Vu, N.; Sakharkar, P.; Tellez-Corrales, E.; Shah, T.; Hutchinson, I.; Min, D.I. Association of vitamin D binding protein polymorphism with long-term kidney allograft survival in Hispanic kidney transplant recipients. Mol. Biol. Rep. 2013, 40, 933-939. [CrossRef] [PubMed]

17. Malik, S.; Fu, L.; Juras, D.J.; Karmali, M.; Wong, B.Y.L.; Gozdzik, A.; Cole, D.E.C. Common variants of the vitamin D binding protein gene and adverse health outcomes. Crit. Rev. Clin. Lab. Sci. 2013, 50, 1-22. [CrossRef]

18. Valdivielso, J.M.; Fernandez, E. Vitamin D receptor polymorphisms and diseases. Clin. Chim. Acta 2006, 371, 1-12. [CrossRef]

19. Levey, A.S.; Bosch, J.P.; Lewis, J.B.; Greene, T.; Rogers, N.; Roth, D.R. A more accurate method to estimate glomerular filtration rate from serum creatinine: A new prediction equation. Ann. Intern. Med. 1999, 130, 461-470. [CrossRef]

20. Shams, S.S.; Vahed, S.Z.; Soltanzad, F.; Kafil, V.; Barzegari, A.; Atashpaz, S.; Barar, J. Highly effective DNA extraction method from fresh, frozen, dried and clotted blood samples. BioImpacts 2011, 1, 183-187.

21. Marcen, R.; Ponte, B.; Rodríguez-Mendiola, N.; Fernandez-Rodriguez, A.; Galeano, C.; Villafruela, J.; Teruel, J.; Burgos, F.; Ortuño, J. Vitamin D deficiency in kidney transplant recipients: Risk factors and effects of vitamin D3 supplements. Transplant. Proc. 2009, 41, 2388-2390. [CrossRef] [PubMed]

22. Hullett, D.A.; Laeseke, P.F.; Malin, G.; Nessel, R.; Sollinger, H.W.; Becker, B.N. Prevention of chronic allograft nephropathy with vitamin D*. Transpl. Int. 2005, 18, 1175-1186. [CrossRef]

23. Battaglia, Y.; Cojocaru, E.; Fiorini, F.; Granata, A.; Esposito, P.; Russo, L.; Bortoluzzi, A.; Storari, A.; Russo, D. Vitamin D in kidney transplant recipients. Clin. Nephrol. 2020, 93, 57-64. [CrossRef] [PubMed]

24. Ma, M.K.; Mok, M.M.; Yung, S.; Tang, C.S.; Chan, T.M. High prevalence of vitamin D insufficiency in southern chinese renal transplant recipients. Ren. Fail. 2012, 34, 980-984. [CrossRef]

25. Bienaimé, F.; Girard, D.; Anglicheau, D.; Canaud, G.; Souberbielle, J.C.; Kreis, H.; Noël, L.H.; Friedlander, G.; Elie, C.; Legendre, C.; et al. Vitamin D status and outcomes after renal transplantation. J. Am. Soc. Nephrol. 2013, 24, 831-841. [CrossRef]

26. Ye, W.-Z.; Reis, A.F.; Velho, G. Identification of a novel Tru9 I polymorphism in the human vitamin D receptor gene. J. Hum. Genet. 2000, 45, 56-57. [CrossRef] [PubMed]

27. Faraco, J.H.; Morrison, N.A.; Baker, A.; Shine, J.; Frossard, P.M. ApaI dimorphism at the human vitamin D receptor gene locus. Nucleic Acids Res. 1989, 17, 2150. [CrossRef] [PubMed]

28. Gross, C.; Eccleshall, T.R.; Malloy, P.J.; Villa, M.L.; Marcus, R.; Feldman, D. The presence of a polymorphism at the translation initiation site of the vitamin D receptor gene is associated with low bone mineral density in postmenopausal mexican-American women. J. Bone Miner. Res. 2010, 11, 1850-1855. [CrossRef] [PubMed]

29. Rubello, M.; Giannini, S.; D’Angelo, A.; Nobile, M.; Carraio, G.; Rigotti, P.; Marchini, F.; Zaninotto, M.; Carbonare, L.D.; Sartori, L.; et al. Secondary hyperparathyroidism is associated with vitamin D receptor polymorphism and bone density after renal transplantation. Biomed. Pharmacother. 2005, 59, 402-407. [CrossRef]

30. Korucu, B.; Tükün, F.A.; Helvaci, Özant; Yeter, H.H.; Gönen, S.; Güz, G.; Arinsoy, S.T. Vitamin D receptor polymorphisms and bone health after kidney transplantation. Turk. J. Med Sci. 2021. [CrossRef]

31. Yao, B.; Chen, X.; Shen, F.-X.; Xu, W.; Dong, T.-T.; Chen, L.-Z.; Weng, J.-P. The incidence of posttransplantation diabetes mellitus during follow-up in kidney transplant recipients and relationship to Fok1 vitamin D receptor polymorphism. Transplant. Proc. 2013, 45, 194-196. [CrossRef]

32. Falleti, E.; Bitetto, D.; Fabris, C.; Cmet, S.; Fornasiere, E.; Cussigh, A.; Fontanini, E.; Avellini, C.; Barbina, G.; Ceriani, E.; et al. Association between vitamin $\mathrm{D}$ receptor genetic polymorphisms and acute cellular rejection in liver-transplanted patients. Transpl. Int. 2012, 25, 314-322. [CrossRef] [PubMed]

33. Azarpira, N.; Sagheb, M.M.; Geramizadeh, B.; Darai, M. Vitamin D receptor genotypes and kidney allograft rejection. Mol. Biol. Rep. 2009, 36, 2387-2392. [CrossRef] [PubMed]

34. Lavin, P.; Laing, M.; O’Kelly, P.; Moloney, F.; Gopinathan, D.; Al Aradi, A.; Shields, D.; Murphy, G.; Conlon, P. Improved renal allograft survival with vitamin D receptor polymorphism. Ren. Fail. 2007, 29, 785-789. [CrossRef]

35. Gombart, A.F.; Borregaard, N.; Koeffler, H.P. Human cathelicidin antimicrobial peptide (CAMP) gene is a direct target of the vitamin D receptor and is strongly up-regulated in myeloid cells by 1,25-dihydroxyvitamin D 3. FASEB J. 2005, 19, $1067-1077$. [CrossRef] [PubMed]

36. Liu, P.T.; Stenger, S.; Li, H.; Wenzel, L.; Tan, B.H.; Krutzik, S.R.; Ochoa, M.T.; Schauber, J.; Wu, K.; Meinken, C.; et al. Toll-like receptor triggering of a vitamin D-mediated human antimicrobial response. Science 2006, 311, 1770-1773. [CrossRef] [PubMed]

37. Daniel, C.; Sartory, N.A.; Zahn, N.; Radeke, H.H.; Stein, J.M. Immune modulatory treatment of trinitrobenzene sulfonic acid colitis with calcitriol Is associated with a change of a T helper (Th) 1/Th17 to a Th2 and regulatory T cell profile. J. Pharmacol. Exp. Ther. 2007, 324, 23-33. [CrossRef]

38. Rech, M.A.; Fleming, J.N.; Moore, C.L. 25-hydroxyvitamin D deficiency and opportunistic viral infections after kidney transplant. Exp. Clin. Transplant. 2014, 12, 95-100. 